folk/ed. 2021; 27(2) $106 \mathrm{Ek}$

DOI: $10.22559 /$ folklor.1757

\title{
Kırmızı Başlıklı Kız'ın Edebiyattan Sinemaya AI Yazmalı Olarak Yolculuğu
}

\author{
The Journey of the Little Red Riding Hood \\ from Literature to Cinema as the Girl with the Red Scarf
}

\section{Süreyya Elif Aksoy*}

\begin{abstract}
Öz
Makale, Cengiz Aytmatov'un Selvi Boylum Al Yazmalım adıyla Rusçadan Türkçeleştirilmiş öyküsü ile aynı adla Atıf Yılmaz'ın yönetmenliğinde ve Ali Özgentürk'ün senaryosu ile yapılmış sinema uyarlamasının, “Kırmızı Başlık1ı Kız” masalının Grimm Kardeşler varyantı ile hem biçimsel bakımdan metinlerarası ilişkiler içinde olduğunu hem de kadın bedeninin ve cinselliğinin denetlenerek ataerkil aile yapısı içinde sınırlanması bağlamında benzer bir toplumsal ve ahlaki işlev üstlendiğini göstermektedir. İncelemede söz konusu üç metin sırasıyla, olay örgüsü, metinlerarası bağları görünür kılan işaretler ve birey-toplum çatışması ekseninde karakterlerin oluşumu açılarından ele alınmıştır.
\end{abstract}

Geliş tarihi (Received): 10.03.2021 - Kabul tarihi (Accepted): 29.05.2021

* Yrd. Doç .Dr., Doğuş Üniversitesi Türk Dili ve Edebiyatı. saksoy@dogus.edu.tr. ORCID 0000-0002-5109-4292. 
“Kırmızı Başlıklı Kız”da metaforik bir anlatımla sunulan ibret hikâyesi, sözü edilen roman ve filmde doğrudan ifade edilmiştir. Kadının, arzulayan ve arzularının peşinde ev dışında deneyimler yaşayan bir özne olarak var olma çabası ile edilgin bir arzu nesnesi olarak ev içinde tutulmasına yönelik baskı arasındaki gerilim, ikinciden yana sonuçlanır. Genç kız, bireysel istekleri ile toplumsal ödevleri arasındaki çatışmayı, arzularını bastırıp erkek egemen yapı içindeki konumunu ve annelik kimliğini kabullenmek yoluyla sonuçlandırır ve böylelikle erginlik eşiğini geçer. Bu üç metin arasındaki bağları ortaya çıkartırken, "Kırmızı Başlıklı Kız” varyantları ve uyarlamaları hakkındaki çeşitli gözlemler ve yorumların yanı sıra, olağanüstü masallardaki karakterlerin işlevleri üzerine geliştirilmiş kavramsallaştırmalardan ve modernlik ile cinsellik tarihi hakkındaki bazı saptamalardan yararlanılmıştır.

Anahtar sözcükler: selvi boylum al yazmalım, toplumsal cinsiyet, masal, öykü, film

\begin{abstract}
Cengiz Aytmatov's story Selvi Boylum Al Yazmalım, translated from Russian into Turkish, and the film adaptation of the same name, directed by AtıfY1lmaz and with the screenplay by Ali Özgentürk, have both formal and intertextual relations with the Grimm Brothers variant of the fairy tale "Little Red Riding Hood". This article displays these relations as well as discuss that these three texts serve a similar social and moral function in the context of controlling and limiting the female body and sexuality within the patriarchal family structure. The study is structured on a comparative close reading of the three texts, in terms of plot, signs that make intertextual ties visible, and the formation of characters on the axis of individual-society conflict. The moral tale metaphorically conveyed in the "Little Red Riding Hood" is directly expressed in the aforementioned story and film. The tension between the woman's effort to exist as a subject who desires and experiences the consequences of her desires outside the home and the forces which try to keep her at home as a passive object of desire, is resolved to the benefit of the latter. The maiden resolves the conflict between her individual desires and her social duties, by accepting her domestic role and maternal identity within the boundaries of the maledominated family, hence she crosses the threshold of puberty. While revealing the links between these three texts, various observations and interpretations on the "Little Red Riding Hood" variants and adaptations, as well as theoretical conceptualizations on the functions of characters in fairy tales were used together with an insight on the history of modernity and sexuality.
\end{abstract}

Keywords: red scarf, gender, tale, short story, film 


\section{Giriş}

Türk dünyası edebiyatlarının önemli figürlerinden olan Kırgız yazar Cengiz Aytmatov'un 1961 tarihli, Kırgızca Kızıl Cooluk Calcalım adlı uzun öyküsü (Kahraman, s. 148) Rusçaya, Topolek moy v Krasnoy Kosinke (Kavağım Kırmızı Eşarplı) adıyla çevrilmiştir (Kolcu, 2002, s.39, s.121). Hikâye, Türkçede 1970'lerden başlayarak yapılan çevirilerle Selvi Boylum Al Yazmalım adıyla benimsenmiştir. Bu makalede, 1974 yılında M. Ethem Gözlü tarafından Rusçadan çevrildiği kaydedilen metin esas alınmıştır. Öyküde, Kırgızistan kırsalında tek başına yürürken karşısına çıkan şehirli kamyon şoförü İlyas'a âşık olan köylü kızı Asel'in, ailesinin dayattı̆̆ kişiyle evlenmekten kaçıp İlyas'la bir yuva kurarak çocuk sahibi olması ancak İlyas'ın evi terk etmesinden sonra bebeğiyle yollara düşüp yol ustası Baytemir tarafindan kurtarılarak, onunla evlenmesi anlatılır.

Öykü, Ali Özgentürk'ün senaryosu ve Atıf Yılmaz'ın yönetmenliğinde sinemaya uyarlanmıştır. Türkan Şoray, Kadir İnanır ve Ahmet Mekin'in başrolleri paylaştıkları Selvi Boylum Al Yazmalım, gösterime girdiği 1978 yılından itibaren ciddi bir izleyici kitlesine ulaşmış, ulusal ve uluslararası ödüller almış ve Cahit Berkay'ın müzikleri ile de bütünleşerek, unutulmaz filmler arasına girmiş̧tir. Popüler kültürde kalıcı yansımaları olan film, aşk ve aile kavramları bağlamında toplumsal bellekte yer etmiştir. Film, edebiyattan sinemaya uyarlamalar bağlamında çeşitli çalışmalara konu olmuşsa da bu çalışmalar, öykü ile filmi, birbirine benzer temalar çerçevesinde ele almış ve filmin aşk üzerine kurulduğuna ilişkin gözlemleri yinelemişlerdir. Oysa filmin odağındaki tutkulu âşıklar sonunda ayrılır ve filmde, emek verilen bir sevgi ve özellikle çocuk sevgisi ile çocuk yetiştirmek için harcanan emek idealize edilir. Asya ile İlyas arasındaki büyük aşk yerini, "Sevgi neydi? Sevgi emekti." repliği ile hafızalara kazınan bir mantık evliliğine bırakır. Asya, geleneklerin kendisine çizdiği yoldan sapan ve arzularının peşinden giden güzel bir köylü kızıdır ama bu kararının ve karşısına çıkan ilk yabancıya güvenip âşı olmasının bedelini öder. Sevdiği adam, başka bir kadınla ilişkiye girer ve evi terk eder; üstelik Asya, evliliğinin de resmi olmadığını öğrenir. Toplum nezdinde "düşmüş" güzel bir kadın olarak kötü bir sona doğru ilerlerken ona ve bebeğine aciyan erdemli bir erkeğin kahramanlığ 1 ile kurtulur. The article begins with a brief literature review on the Little Red Riding Hood which illustrates the milestones of the journey of the tale from oral tradition to French and German children's literature. I carried out a comparison of these versions and their representation in Turkish throughout my analysis. Although Selvi Boylum Al Yazmalım shares a similar plot with the Grimms' version of the tale in terms of their heroines being saved at the end, I also made references to the Perrault's version which contains a strict moral message complementing the socio-cultural aspect of the tale and tying it with Selvi Boylum Al Yazmalım even further. The article also questions the misogynist interventions of Grimm Brothers on the tale and takes a note of the quasi-feminist influence of one of their story-teller sources who is reported to be influential in softening the horrible end of the little girl dictated by Perrault. 
Filmde Asya'nın, öyküde Asel' in yaşadığına benzer kurtuluş hikâyeleri masallarda da vardır. Masallar, sözlü kültürlerde doğan, sonradan yazıya geçirilip kitaplaşsalar da çoğu kez anneler ve ninelerin dilinden kuşaktan kuşağa devam eden anlatılardır. Avrupa'da matbaanın yaygınlaşmasına koşut olarak modern dönemde masallar çeşitli derlemelere konu olarak çocuk edebiyatının ilk kaynağını oluşturmuşlardır. Kırmızı Başlıklı Kız, bilinen ilk yazılı örneği 17. yüzyıl sonlarında (1697) Fransa'da Charles Perrault tarafından yayımlanmış; sonraki yüzyıllarda, çeşitli dillerde çok sayıda varyantı ve operet, roman, film gibi birçok türe uyarlaması yapılarak evrensel nitelik kazanmış bir masaldır. Perrault, Kırmızı Başlıklı Kız'ın evinden çıkıp hasta büyükannesine yiyecek ve içecek götürmek üzere ormanda yürürken başına gelenlerden oluşan ünlü serüvene, bugün yaygın olan mutlu sonun aksine acı bir son yazmıştır. Masalın sonunda kurt, kızı da büyükannesini de yer ve ortaya hiçbir kurtarıcı çıkmadan masal biter. Annesinin uyarılarının dışına çıkarak ormanda karşılaştığı kurtla konuşan ve onun gösterdiği yoldan çiçek toplayarak doğanın güzelliklerinin tadını çıkaran küçük kız ve onunla gizemli bir ortaklık içinde olduğu hissini veren büyükanne ağır biçimde cezalandirilırlar.

Modernleşmenin ilk aşamalarında Avrupa'da, aile yapısında yaşanan dönüşüm ve cinsel özgürleşme, istenmeyen hamilelikler ve babasız çocuklar sorununu ortaya çıarır. Bu çerçevede, Fransa'da aristokrat aileler, kız çocuklarını ergenliğe geçiş sürecinde erkeklerden gelecek tehlikelere karşı uyarmak için masallara başvurur ve iyi eğitimli mürebbiyeler tarafından anlatılan ya da okunan masallarla kız çocuklarını uyarır. Böylelikle masallara ahlaki bir görev yüklenmesi, masalların içeriğine de yansır; sözlü gelenekte anlatılan örneklerinde güçlü ve görece özgür kadın karakterlere yer veren masalların yerini, edilgen ve erkekler tarafindan kurtarılmayı bekleyen kadın karakterler almaya başlar. Bu değişimde, çeşitli kaynaklardan derledikleri masallar üzerinde ciddi müdahaleler yapan Perrault gibi yazarların rolü de büyüktür. Derledikleri masallara yaptıkları bu tür değiştirmeler nedeniyle sonraları eleştirilere konu olan masal yayımcılarının arasında Grimm Kardeşlerin de özel bir yeri vardır.

Masalın, 19. yüzyılda Almancaya çevirisini yapan Wilhelm ve Jacob Grimm (bundan sonra Grimm Kardeşler ), masalı, çeşitli değiştirimlere tabi tutmuşlar ama Fransız versiyonundaki trajik sonu değil, sözlü gelenekte çok daha eski örneklerinde yer alan 1lımlı bir sonu tercih etmişler ve Kırmızı Başlıklı Kız ile büyükannesini, bugün en yaygın bilinirliğe sahip olan mutlu sona ulaştırmışlardır. Deneyimsiz kız, hiç tanımadığ 1 birine, kurda güvenip yoldan çıkmakla hata yapmıştır ama ona, hatasından ders çıkarma ve akıllanmış olarak hayatına devam etme şansı verilir.

Kırmızı Başlıklı Kız üzerine yaptığı feminist okumalarla bilinen masal araştırmac1s1 Jack Zipes (1993), sözünü ettiğimiz yazılı varyantların öncesinde, bu masala dair bir sözlü geleneğin olduğuna dikkat çeker. Folklor eserlerinde "ilk örnek" saptamak çok zor olsa da araştırmacı Paul Delarue, Kırmızı Başlıklı Kız’ın, sözlü gelenekte uzun yıllardır anlatılagelen bir masal olduğunu ve bunun, kız çocuğunun kendisini koru- 
masını öğrenerek büyükannesiyle birlikte sağ çıktığı bir anlatı olduğunu saptamıştır (Zipes, 1993, s.21). Masalın sözlü kültür versiyonunda, içine düştüğü kötü durumlardan ninesiyle birlikte kurtulmayı başaracak kadar becerikli bir köylü kızı profili çizilir ve bu durum bir ölçüde, üretime katılan köylü kadının belli bir gücü ve özerkliğinin olduğu tarım toplumlarının özelliklerinden kaynaklanmaktadır.

Jack Zipes (1993), Kırmızı Başlıklı Kız masalının, sözlü gelenekteki izlerinden, popüler kültürdeki uyarlamalarına kadar uzanan geniş bir tarihsel çizgideki evrimini ortaya koyduğu çalışmasında masalın, Fransız ve Alman versiyonlarının Perrault ve Grimm Kardeşlerin yoğun müdahaleleri ile ortaya çıktığını ve böylelikle masalın, ataerkil yapı içinde kadın bedeninin ve cinselliğinin denetim altına alınmasına hizmet eder hâle geldiğini söyler. Jack Zipes'ın, edebî tür hâline gelmiş masalların, 17. yüzyılda Fransa'da bilinçli olarak geliştirildiğini ve "modern Avrupa' da cinselliğin denetim altına alınması" amacını güttüğünü belirttiği, The Trials and Tribulations of Little Red Riding Hood (Kırmızı Başlıklı Kızın Sınavları ve Sıkıntıları) adlı kitabı, 1983'te ilk kez yayımladı̆̆ında geniş yankı uyandırmıştır (Zipes, 1993, s. xi). Zipes bu kitapta, masallarda sunulan doğru ve yanlış davranışlar ile toplumsal cinsiyet rollerinin, dönemin toplumsal normlarının şekillenmesinde büyük etkileri olduğunu öne sürerek masal ve toplumsal cinsiyet çalışmaları eksenine önemli bir katkıda bulunmuştur. Zipes bu kitabında ayrıca, bazen başına türlü belalar gelip kurda yem olsa da yüzyıllardır sadece Avrupa'da değil dünya üzerinde çok geniş bir coğrafyada çeşitli biçimlerde yeniden doğan Kırmızı Başlıklı Kız'ın, modern roman ve sinemadaki uyarlamalarından ve onun bu tartışmalı mirasıyla hesaplaşmak üzere feminist bakış açısıyla üretilen metinlerden çarpıcı örnekler vererek geniş bir Kırmızı Başkılı Kız külliyatı sunar.

$\mathrm{Bu}$ makalede, Cengiz Aytmatov'un Selvi Boylum Al Yazmalım adlı uzun öyküsü ile öykünün, Atıf Yılmaz'ın yönetmenliğinde yapılmış aynı adlı sinema uyarlaması, bugüne dek yerleştirildikleri yerel kültürel bağlamlarının ötesinde, 20. yüzyıl başlarında tüm dünyaya yayılmış olan Batı kaynaklı bir masal olan Kırmızı Başlıklı Kız ile birlikte ele alınacaktır. Böylelikle, ilk bakışta belli bir kültüre özgü görünen hikâyelerin benzer ataerkil şemaları yeniden üretecek biçimde nasıl birbirleriyle etkileşim içinde oldukları gösterilecektir. Öykü ve filmin, sözü edilen masalın, dünyada en yaygın olarak bilinen Grimm Kardeşler varyantı ile hem biçimsel bakımdan metinlerarası ilişkiler içinde olduğu hem de kadının ataerkil aile yapısı içinde sınırlanması bağlamında benzer bir toplumsal ve ahlaki düzlemde konumlandıkları sergilenecektir. Son olarak, sözü edilen ataerkil denetime karşı, dişil direnç dinamiklerinin var olup olmadığı tartı̧̧ılacaktır.

İncelemede, söz konusu üç metni sırasıyla, olay örgüsü, metinlerarası bağları görünür kılan işaretler ve sosyokültürel bağlam ekseninde karakterlerin toplumla çatışmaları açılarından ele alacağız. Kırmızı Başlıklı Kız'da metaforik bir anlatımla, daha çok çocuk okuyucu kitlesine yönelik olarak sunulan ibret hikâyesi, sözü edilen öykü ve filmde daha doğrudan ve yetişkinleri hedef alan bir dille ifade edilmiş; kadının, arzula- 
yan ve arzularının peşinde, ev dışında bir maceraya atılan bir özne olarak var olma çabası ile erkek tarafindan arzulanan ve ev içindeki toplumsal cinsiyet rolüne indirgenen bir kadın figürüne dönüşmesi arasındaki gerilim odağa alınmıştır. Bu konuda öykü ile film arasındaki önemli bazı ayrımlara da değinilecektir; öyküde Asel'in bakış açısına hiçbir biçimde yer verilmediği için göremediğimiz kadın bakış açısı ve iç çatışmaları, filmde Asya'nın aşk ile aile arasındaki bocalamasında ve ataerkil kalıplara direnen bireyselliğinde yoğun olarak görmek mümkündür. Birey olma çabası ile toplumsal ödevleri arasındaki çatışmanın odağındaki genç kız, arzularını bastırıp erkek egemenliğindeki kutsal ailenin sınırlarını ve buradaki edilgen rolünü kabullenmek yoluyla erginlik aşamasını tamamlar, büyür. Bu üç metin arasındaki bağları ortaya çıkartırken Perrault ve Grimm Kardeşlerin Kırmızı Başlıklı Kız varyantlarından, Vladimir Propp'un olağanüstü masallardaki karakterlerin işlevleri üzerine geliştirdiği kavramsallaştırmadan, metinlerarasılık üzerine gözlemlerden, modernlik ile cinsellik tarihi hakkındaki yorumlar ile feminist masal çalışmalarının bazı bulgularından yararlanacağız.

\section{Bir hikâye, birçok metin}

Alan Dundes (1989), Kırmızı Başlıklı Kız masalını konu alan çalışmalarda çoğunlukla Charles Perrault tarafindan yayımlanan Fransiz versiyonu (Le petit chaperon rouge) ve Grimm Kardeşlerin derlemesinde yer alan Alman versiyonu (Rotkäppchen) üzerinde durulduğunu oysa köklü bir sözlü gelenekten beslenen bu masalın çok daha geniş bir çerçevede ele alınması gerektiğini vurgulamıştır (s. ix). Kırmızı Başlıklı Kız masalı, bilindiği kadarıyla Avrupa'da ilk kez 17. yüzyılda Charles Perrault tarafından yazıya geçirilmiştir (Dundes, 1989, 3). 1697 tarihli Perrault versiyonu ve bu metinle birlikte birçok masal anlatııısının yardımıyla oluşturulan Grimm Kardeşler versiyonu (1812), masalın yazılı ve edebî kolunu yönlendirmiş, biçimlendirmiş̧ir (Dundes, 1989, ix).

Jacob ve Wilhelm Grimm, içinde Kırmızı Başlıklı Kız’ın da bulunduğu kitaptaki (Kinder und Hausmärchen) masalları, Alman köylülerinden derlediklerini iddia etseler de araştırmacılar, bu yöntemin, kitaptaki masalların tümü için doğru olmadığını; Grimm Kardeşlerin çeşitli kaynaklardan topladıkları masal versiyonlarının bazı ögelerini bir araya getirerek bileşik metinler ortaya çıkardıklarını saptamışlardır (Dundes, 1989, s.7). Dundes (1989), Kırmızı Başlıklı Kız masalının Grimm versiyonunun kaynağının, "bir düşesin nedimeliğini yapan ve dolayısıyla orta-üst sınıfa mensup ve kısmen Fransız kökenli bir kadın olan Marie Hassenpflug" olduğunu vurgulayarak Alman köylülerinden çok farklı bir kaynağa işaret etmiştir (s.8). Bu versiyonda kız ve ninesi, ilk kurdun karnından bir avcı tarafından kurtarılırlar, daha sonra ikinci bir kurt saldırısını ise kendi akılları sayesinde savuşturup kurdu öldürürler. Gerek Cengiz Aytmatov'un Selvi Boylum Al Yazmalım adlı öyküsü, gerek bu öykünün sinemaya uyarlanmasıyla ortaya çıkan film, Kırmızı Başlıklı Kız masalının Grimm Kardeşler versiyonunun olay örgüsüne uygun bir yap1 sergilemektedir. Bu nedenle makalede, masalın Grimm Kardeşler versiyonu temel alınmış ancak pek çok aşamada Perrault 
versiyonu ile de karşılaştırmalar yapılmıştır. Grimm Kardeşler versiyonunun güncel Türkçe çevirisinde, masalın Jack Zipes tarafından yapılmış İngilizce çevirisine (Zipes, 2014) göre bazı eksikler ve değiştirmeler saptandığından, İngilizce çeviriyle örtüşen bölümlerde Türkçe bask1, iki metin arasında uyuşmazlık olduğu durumlarda İngilizce çeviri esas alınacak ve kaynak buna göre gösterilecektir.

\section{Olay örgüsü: Yoldan sapan küçük kızın felaketi ve kurtuluşu}

Vladimir Propp (2017) olağanüstü masalların karakterlerini, masal içinde oynadıkları işlevlere göre sınıflandırdığı çalışmasında birçok anlatı türü için geçerli olan evrensel bazı eylemler sıralamıştır. Bunlar arasında, deneyimsiz bir kahramanın evden uzaklaşması, bir yasakla sınırlandırılması ve bu yasağı çiğnemesi, saldırganın kurban seçtiği kahraman hakkında bilgi edinmeye çalışması, kahramanın aldanarak bilmeden saldırgana yardım etmesi ve saldırganın aileden birine zarar vermesi, kahramanın saldırıdan kurtularak evine dönmesi gibi işlevler yer almaktadır (s. 29-33). Kırmızı Başlıklı Kız, Selvi Boylum Al Yazmalım öyküsü ve aynı adlı film, bu işlevlerin tümünü barındırmaktadır; odaktaki karakter, yasağı çiğnediği için saldırıya uğrar ama tehlikeden kurtulur ve eve döner. Bu süreçte ise deneyim kazanır ve olgunlaşır.

\subsection{Yasağı çiğneme ve yoldan çıkma}

Üç metinde de kızın izlemesi gereken bir yol ve onu bu yoldan çıkmaması için uyaran, sınırlayıcı bir anne figürü vardır. Kırmızı Başlıklı Kız, hasta büyükannesine gitmek üzere evden çıkar; öyküde Asel, çalıştı̆̆ haradan eve dönmek üzere, filmde Asya süt götürmek için yoldadır. Masalda anne, "Güneş tepeye çıkmadan önce yola koyul, dışarıda da uslu uslu yürü, yolun dışına çıkma" uyarısında bulunur (GK, 2015, s.63). Masalın Perrault versiyonunda annenin hiçbir uyarısı yoktur, yalnızca kıza büyükannesinin hasta olduğunu ve ona çörek ile bir kap tereyağı götürmesini söyler (Perrault, 1989, s. 3).

Öyküde, anlatı İlyas'ın bilinciyle sınırlı olduğu için Asel'in evden ayrılmasına ilişkin bir sahne yoktur. Ancak, burada da kızı sert biçimde uyaran, yasaklayıcı bir anne figürü vardır. Asel ile İlyas'ın tanıştıkları, birazdan ayrıntılı olarak anlatacağımız sahnenin devamında İlyas, kızı kamyonuyla evine bırakır; İlyas, Asel'in yalvarmasına aldırmadan kızı evinin önüne kadar kamyonuyla götürür. Kızının geldiğini görünce evden sinirle çıkan annenin betimlenmesi ve sözleri, tam bir namus bekçisi anne tipi oluşturmaktadır: "[E]vin kapısı açılarak yaşlıca bir kadın çıktı dışarıya. Kadının tedirgin bir görünüşü vardı. Asel, kız! diye bağırdı! Hay, boyun devrilsin e mi? Ne cehennemlerde kaldın?" (Aytmatov, 1974, s. 190). Aynı aksi anne, başka bir gün, evin yakınında Asel'i bekleyen İlyas'1, sert biçimde uyarır: "Hey, delikanlı, bakıyorum da buraya iyi dadandın! Evin önü han değil, anladın mı? Hadi, çek git bakalım!" (Aytmatov, 1974, s. 201). Asel aile kararıla bir akrabalarıla evlendirilecektir ve evlenme çağına yeni adım atmış "güzel" bir kız olduğu için üzerinde anne ile temsil edilen güçlü bir aile baskısı vardır. 
Benzeri bir baskı, Selvi Boylum Al Yazmalım filminin de açılış sahnesinden itibaren hissedilir ve üstelik Aytmatov'un öyküsünde yer almayan, kızın evden ayrılma sahnesi, filmde Kırmızı Başlıklı Kız masalının açılış sahnesinin özünü, olumsuz bir anne figürüyle yeniden üretmiş görünmektedir. Aksi ve öfkeli anne Asya'ya sert uyarılarda bulunur, güzelliğini gizlemesi için yüzüne is sürer. Asya, "Ana vallahi iyice dellendin sen. Burda kim bakacak benim yüzüme" diye itiraz ettiğinde, anne şu cevabı verir: "Her yer it kopuk dolu, bakarlar. Eskisi gibi mi?". Anne-kızın evlerinin olduğu yerde baraj inşaatı vardır, onların evini de almak istemektedirler; Asya evi satıp şehre gitmeyi çok istese de annesi buna direnmekte kararlıdır. Bir yandan da baraj inşaatı nedeniyle o bölgeye dışarıdan gelen kişilerden rahatsızdır. Kızını korumaya çalışmas1 anlaşılabilirse de bu annenin davranışlarında, mimiklerinde ve sözlerinde herhangi bir sevgi işareti görülmemesi dikkat çekicidir: "Bir evlen de, sonra ne bok yersen ye! Şehri de çıkar aklından". Asya belki şehre gidemeyecek ama bu sahneden hemen sonra tanışacağı İstanbullu kamyon şoförü İlyas'ta kaçış umudu bulacak ve İlyas'la buluşmak üzere evden her çıktığında önce al yazmasını saklayıp yüzünü simsiyah yaparak annesini memnun edecek ama evden uzaklaşır uzaklaşmaz yüzünü silip al yazmayı da başına takacaktır. Aslında, filmin açılış sahnesinde Asya'nın evden ayrılışı, filme temel oluşturan Aytmatov'un öyküsünün özgün bir yorumdur. Öyküde kız eve dönerken beliren yaşlıca ve çok aksi anne, filmde en başta, kız evden ayrılırken sahneye çıkar. Filmin bu sahnesini, Aytmatov'un metninden ayıran bir özellik de Asya'nın, annesinin tüm kısıtlamalarına karşın bir aşk yaşamaya hazırlanan taşkın neşesinin vurgulanmasıdır. Yüzüne annesi istediği için kara çalarken mutsuzluğu ve daha sonra yüzünü yıkayıp al yazmasını başına taktığında ışıldayan güzelliğiyle gelen sevinci, izleyiciyi olayların devamına hazırlar niteliktedir.

\subsection{Küçük kızları ormanda bekleyen tehlikeler}

Masalda Kırmızı Başlıklı Kız, hastalanan büyükannesine gitmek için annesi tarafindan görevlendirilir. Büyükanne, Fransız versiyonunda "başka bir köyde" yaşamaktadır ve küçük kız buraya ulaşmak için bir ormandan geçmek zorundadır (Perrault, 1989, s. 4). Büyükanne, Grimm Kardeşlerin (1989) metninde ise "köyden yarım saat uzaklıkta bir ormanda" yaşamaktadır (s.9). Her iki durumda da kızın yolu bir ormandan geçmektedir; orman, güzelliklerle ama bilinmezliklerle ve tehlikelerle de dolu bir yerdir. Kırmızı Başlıklı Kız bu yolda ilerlerken karşısına bir kurt çıkar. Propp'un saptadığı gibi istemeden kendi düşmanına bilgi veren kız, kurdun kibarlığı ve güzel sözlerine kanıp ona büyükannesinin evinin yerini tarif eder ve kurdun önerdiği gibi çiçek toplamak için yolunu değiştirmeyi kabul eder: "Kurdun ne kadar kötü bir hayvan olduğunu bilmiyormuş, bu nedenle ondan hiç korkmamış" (GK, 2015, s. 63; Perrault, 1989, s. 4). Kız ormanda çiçek toplarken kurt yolunu öğrendiği büyükannenin evine varır ve büyükanneyi yiyip onun kıyafetleriyle yatağa uzanır. Kız eve vardığında, bir tuhaflık sezmesine rağmen sezgilerine ve annesinin uyarılarına kulak asmayıp kurdun isteği üzerine yatağına girer: 
“ 'Günaydın' diye seslenmiş ama bir yanıt alamamış. Bunun üzerine yatağa girip örtüyü çekmiş - büyükanne orada başlığını iyice yüzüne çekmiş yatıyormuş ve çok tuhaf görünüyormuş" (GK, 2015, 65). Sonrasını biliyoruz; kurdun kulakları, gözleri, elleri ve en nihayetinde ağzının ne kadar büyük olduğuna ilişkin şaşkınlık ifadeleri ve kurdun bunlara verdiği yanıtlarla tekerlemeyi andıran sahneden sonra kurt kızı yutar.

Masalda metaforik bir örüntüyle anlatılan ve çocukların dünyasıyla sınırlı gibi görünen hikâyeyi, öyküde ve filmde yetişkinler arası ilişkilerde takip edebiliriz. Öyküde Asel, filmde Asya genç, güzel ve evlenme çağında köylü kızlarıdır ve büyük şehirden gelen bir yabanc1 erkek, tatlı dili ve cazibesiyle onlara hiç bilmedikleri hazlar vaat eder. Yol hem masaldaki gibi kızların evlerinden çıkıp kat etmeleri gereken sahici bir yol olarak metinlerde belirir hem de bir metafordur; yetişkin birer genç kadın olmak için izlemeleri gereken, ailenin ve toplumun çizdiği yol ile ona alternatif olarak bir erkeğin ayartmasıyla girecekleri yanlış yol arasında bir etkileşim vardır. Belki de birey olabilmek için yanlış da olsa önce kendi istedikleri yola girip deneyim kazanmaları gerekmektedir.

Masalda kurt belirgin bir tehlikedir, Kırmızı Başlıklı Kız'1 ve ninesini yer, yok eder. Öyküde ise İlyas, Asel'i baştan çıkarıp resmi nikahsız birlikte olduktan sonra kucağında çocuğuyla terk ederek toplum nezdinde saygınlığını yok eden büyük bir tehlikedir. Gerçekte her ikisi de doğalarının gereğini yapmaktadır; karnı acıkmış kurt, karşısına lezzetli bir yiyecek çıktığında onu elde etmek için elinden geleni yapar. İlyas da genç ve güzel bir kızı görünce onu arzulayan bir genç adamdır. İlyas, Asel'i her gün ziyarete giderek, kamyonuyla gezdirerek baştan çıkarır, birlikte kaçar ve Asel'in evlilik sandığ ama hiçbir resmiyeti olmayan bir törenden sonra birlikte yaşamaya başlarlar. Ama emek verip sebat ederek sonuç beklemek İlyas'a göre değildir; Asel'den önceki hayatındaki zaaflarına, içki ve geçici tensel ilişkilere geri döner; Asel ile birlikte kurdukları yuvadan uzaklaşmaya başlar.

Asel, İlyas'ın, Kadiça isimli kadınla yaşamaya başladığını öğrendiğinde bebeğini alıp evi terk eder. Anlatı İlyas'a odaklı olarak devam ettiğinden, öykünün bu noktasında Asel anlatı kapsamından tamamen çıkar; bebeğiyle nereye gitmiştir, ne yapmıştır, bu aşamada bilemeyiz; İlyas'1 izlemeye devam ederiz. İlyas, haberi alır almaz Asel'in annesinin evine gidip Asel'i aradığını söyler ve kızın annesi tarafından terslenir; aradan birkaç sene geçtikten ve Kadiça'dan ayrıldıktan sonra tekrar ailesinin evine gelip Asel'i sorduğunda ise Asel'in yeniden evlendiğini ve ailesini de düzenli olarak ziyaret ettiğini öğrenir (Aytmatov, 1974, s. 252). Haberi veren Asel'in kız kardeşidir: "Her y1l eniştemle gelirler. Annem onun iyi bir insan olduğunu söylüyor (Aytmatov, 1974, s. 252). Bu iki olay arasında Asel'in, evinden ayrılıp tekrar başka biriyle evlenene kadar ne yaşadığı yansıtılmaz ama bir sonraki alt bölümde ele alacağımız gibi Baytemir'le karşılaşarak yaşadığı kurtuluş, atlattığı büyük tehlike hakkında fikir verecektir.

Olay örgüsü Aytmatov'un öyküsü ile aynı eksen üzerinde ilerleyen film, 3 ve 4. bölümlerdeki incelemelerde ayrıntılı olarak ele alınacağından, tekrarı önlemek amacıyla buradan itibaren ağırlıklı olarak masal ve öykünün karşılaştırmasına yer verilmiştir. 


\subsection{Kurtuluş ve eve dönüş}

Masalın Fransız versiyonunda olay örgüsü, kurdun büyükanneden sonra kızı da yutmasıyla son bulur. Böylelikle küçük kızın hatasının bedelini büyükanne-torun birlikte, hayatlarıyla öderler. Grimmlerin metninde ise kurt, kızı da yuttuktan sonra yatakta büyük bir gürültüyle horlayarak uyumaktayken, oradan geçmekte olan avc1 sesleri duyarak gelir ve kurdun karnını makasla keserek önce Kırmızı Başlıklı Kız’1 ve daha sonra kızın yardımıyla büyükanneyi çıkartır (GK, 2015, 65). İkisi de kurtulur.

Aytmatov'un yazdığı öyküde Asel'in, evi terk ettikten sonra yaşadıklarını, öykünün "Yol Bakım Ustasının Öyküsü" başlıklı ikinci bölümünde, genç kadının kurtarıcısı olan Baytemir'den öğreniriz. Asel, evi terk ettiği gün, kucağında 10 aylık bebeğiyle, gidecek hiçbir yeri olmadan yağmurun altında ilerlerken, yoldan geçen bir kamyon durur ve anne ile bebeğini alır. Kamyonun arkasında Baytemir ile hastanede tedavi ettirip evine götürmekte olduğu yaşlı bir kadın vardır. Baytemir Asel'in sürekli ağlayan bebeğini kucağına alır, ısıtır ve gidecek bir yerleri olmadığını anlayarak geceyi kendi evinde geçirmelerini teklif eder (Aytmatov, 1974, s. 281). Bunu yaparken de özellikle vurgular: "Korkacak bir şey yok! dedim onu yatıştırmak için. Benden bir kötülük gelmez size. Yol bakım ustasıyım, adım Baytemir Kulov. Bana güvenebilirsiniz." (Aytmatov, 1974, s. 281). Gerçekten de Baytemir güvenilecek biridir, eşini ve kızını çı̆̆ altında yitirdiğinden beri aile özlemi çeken, çalışkan, yardımsever, iyi bir insandır ve Asel ile oğluna güvenli ve sıcak bir yuva sunar. Filmde de olaylar tamamen aynı şekilde cereyan eder.

Ele alınan üç metinde de (masal, öykü ve film), deneyimsiz genç kızın, yasak çiğneyip ormanda karşılaştığı bir yabancıya kapılarak başlayan serüveni, trajik bir sona doğru ilerlerken kahraman bir kurtarıcının mucizevi biçimde ortaya çıkmasıyla güvenli bir evde son bulur.

\subsection{Kurdun geri gelişi ve akıllanmıș kızın kendini koruması}

Kırmızı Başlık Kız masalının Grimm Kardeşler tarafından yayımlanan versiyonunda ilk kurttan kurtulan kız ve büyükannesine ikinci bir kurt saldırır: "Bir rivayet olunur ki, Kırmızı Başlıklı Kız yaşlı büyükannesine bir defa daha pasta götürürken, karşısına başka bir kurt çıkmış ve onu yine yolundan saptırmak istemiş" (GK, 2015, s. 66). Kız bu kez akıllanmıştır; kurt yolda karşısına çıkıp ona selam verdiğinde hiç cevap vermeden "dosdoğru yoluna gitmiş" ve büyükannesini de uyarmıştır " (GK, 2015, s. 66). Kurt yine de 1srarcıdır, kızı takip ederek büyükannenin evine kadar gelip kapıyı çalarak “Kapıyı aç büyükanne, ben Kırmızı Başlıklı Kız’ım, sana pasta, börek getirdim" der ancak büyükanne ile torun birlikte kurda tuzak kurarlar, evin damına çıkmış olan kurdun hoşuna gidecek sosis kaynatılmış suyu evin dışındaki büyük yalağa dökerler, kurt damdan aşağı başını uzatınca dengesini kaybedip yalağın içine düşer ve boğulur (GK, 2015, s. 66). 
Masaldaki ikinci kurt tehlikesine benzer biçimde Selvi Boylum Al Yazmalım adlı öyküde de İlyas Asel'in peşini bırakmaz, sık sık kızın ailesinin evine giderek bilgi almaya çalıştı̆̆ gibi Asel'i tesadüfen bulduğunda yeniden kazanmak için çaba gösterir. Ayrılıklarının üzerinden birkaç y1l geçtikten sonra, İlyas kamyonu bozulup yolda kalır ve ona yardım etmek için kendisini eve götüren kişinin, Asel'in yeni eşi Baytemir olduğunu öğrenir. İyiliksever Baytemir, İlyas'1 evine götürdüğünde İlyas, karşısında Asel'i ve oğlu Samet'i bulur. Durumu Baytemir'e belli etmezler ama İlyas, sevdiği kadını ve oğlunu geri kazanmak için ısrar etmeye başlar. O gece evde konuk olarak kalmış, küçük Samet'le, kendi oğluyla oyunlar oynamış ve ertesi sabah arızalı aracının başına gitmiş olan İlyas, Baytemir'in de yardımıyla kamyonunu ça1ıştırdığ 1 anda, Asel'i kendisiyle gitmeye ikna etmeye çalışır: "—-Asel! dedim arabanın açık kapısından eğilerek. Çocuğu al da atla içeri! Seni o zamanki gibi götüreyim! Artık bir daha ayrılmayacağız! Hadi bin yanıma!" (Aytmatov, 1974, s. 265). Aslında Baytemir çok yakındadır ama motorun gürültüsünden İlyas'ın söylediklerini duymaz. Asel hiçbir cevap vermez: " - Gözleri dolduğu için yana döndü, başını 'olmaz' dercesine salladı" !" (Aytmatov, 1974, s. 265). Aytmatov, Asel'in duyguları hakkında yalnızca bu küçük ipucunu verir; gözleri dolmuştur, muhtemelen İlyas'1 hâlâ sevmektedir ama teklifini kabul etmeyecek kadar da deneyim kazanmıştır. Filmde bu sahne, yukarıda aktardığım karar ânının odağında görsel ve sözel olarak zenginleştirilerek ve kadının duygularına yoğunlaşan bir anlatım diliyle kurgulanmıştır.

Öykünün ve filmin olay örgüsü, Kırmızı Başlıkı Kız masalının Grimm versiyonuyla örtüşmektedir. Çocukluktan gençliğe adım atmak üzere olan bir kız, ailesinin koyduğu yasakları çiğneyerek cazip bir yabancı erkekle yakınlaşmış, onun gösterdiği yanlış yoldan gidip o erkek tarafindan "yutulmuş" ve yok olmak üzereyken başka bir erkeğin yardımıyla kurtarılmıştır. Artık döneceği tek bir yer vardır; terk ettiği kurallı yaşam ve aile yuvası. Masalın sonunda Kırmızı Başlıklı Kız, ikinci kurdun saldırısından birlikte kurtulduğu ninesinin evindedir. Öyküde ve filmde ise kurtarıcı erkeğin kıza sunduğu yuvada, aile kurumunun koruması altındadır.

Selvi Boylum Al Yazmalım'ın bir Kırmızı Başlıklı Kız uyarlaması olduğunu veya bu masaldan ögeler barındırdığını söylemek için yalnızca olay örgüsünü temel almak derinlikli bir okuma olamaz. Merkezinde, iki erkek arasında seçim yapması gereken genç, deneyimsiz ve kapılmaya hazır bir genç kızın olduğu birçok anlatı bulabiliriz. Ama makalede ele aldığımız üç metin arasında metinlerarası ilişkiler kuran işaretler veya göstergeler ile yine hepsinin ilişkilendirilebildiği bir sosyokültürel bağlamı fark ettiğimizde böyle bir karşılaştırmadan söz edebiliriz. Bundan sonraki iki bölümde sırasıyla bu konular tartış1lacaktır.

\section{Metinlerarası işaretler: Al yazma, nine, tehlikeli}

\subsection{Kırmızı başlık-al yazma}

Olay örgüsünde görülen koşutluk, simgesel önemi olduğu anlaşılan bazı anlatı ögeleriyle de desteklenir. Kırmızı başlık ve al yazma arasındaki benzerlik, bu ögelerin 
en görünür olanıdır. Selvi Boylum Al Yazmalım öyküsünün, Aytmatov tarafından yapılan Rusça çevirisinde de (Topolek moy v Krasnoy Kosinke/Kavağım Kırmızı Eşarp11), İngilizce baskısında da (My Poplar in a Red Kerchief/Kırmızı Eşarplı Kavağım) kırmızı eşarp ögesinin yer aldığı görülmektedir. (Kolcu, 2002, s. 39). Makaleye konu öyküde ve filmde, annenin yasakladığı ama kızın inatla taktığı al yazmanın önemli bir konumu vardır.

\subsection{Nine}

Masal-öykü-film ekseninde süreklilik gösteren diğer bir öge, büyükanne veya nine figürüdür. Masalda kız, hasta büyükannesine yiyecek ve içecek götürmekle görevlendirilir ve ikisi arasındaki gizemli bağ daha ilk cümlelerde imlenir: "Bir zamanlar küçük, şirin bir köylü kızı varmış; şöyle bir bakanlar bile onu çok severmiş. Bu küçük kızı en çok seven kişi de büyükannesiymiş" (GK, 2015, s. 63). Üstelik kıza kırmızı başlı̆̆ını vererek ona kimlik kazandıran da büyükannesidir: "Bir gün büyükannesi kıza kırmızı kadifeden bir başılı hediye etmiş. Bu başlık çok yakışınca, kız da başka bir başlık takmak istememiş. Bundan böyle küçük kızı 'Kırmızı Başlıklı Kız’ diye çağırır olmuşlar” (GK, 2014, s.63). Küçük kız ile büyükanne tehlikeler karşısında da birliktedir; Perrault versiyonunda kurdun karnında birlikte ölürler, Grimm Kardeşler metninde ise ikinci kurdu birlikte alt ederler.

İncelediğimiz öykü ve filmde bir nine karakteri yoktur. Ancak, öykünün en can alıcı sahnesi sayılabilecek, Asel ile İlyas'ın tanışmaları sırasında beliren bir nine imgesi vardır. Asel ile İlyas'ın ormanda ilk karşılaşmalarında İlyas, kamyonunu saplandığı çamurdan kurtarmaya çalıştığı sırada, eğildiği yerden baktığında kamyonunun arkasında bir çift çizme görür ve bunların yaşlı bir kadına ait olduğunu zanneder: "Aşağıdan, gözümün ucuna eski püskü, gübreye bulanmış bir entari eteği ilişti. 'Köye kadar bırakıvermem için bekleyen yaşlı bir kadın' diye geçirdim içinden. 'Git yoluna, nine! Benim işim hemen bitmez, boşuna bekleme! diye bağırdım" (Aytmatov, 1974 s. 186). Ama çizmeler bir nineye değil genç ve güzel bir kıza, Asel'e aittir; Asel'in nineye benzetilmesi ile Kırmızı Başlıklı Kız'ın büyükannesine bir anıştırma yapılır. Al Yazmalı ile nine, Kırmızı Başlıklı Kız ile Büyükanne iç içe geçerek akışkan bir imge oluşturmuşlardır. Film, genç kız ile nineyi bütünleştiren bu sahneyi, etkili bir görselleştirme ile özünü olduğu gibi koruyarak almıştır. Öykü ve film hakkında ayrı ayrı ya da sinemaya uyarlama bağlamında bugüne kadar yapılan çalışmalarda, kızın bir nineye benzetildiği bu sahnenin üzerinde bildiğimiz kadarıyla hiç durulmamıştır.

Konu masal olduğunda nine, kuşkusuz önemli bir figürdür. Pertev Naili Boratav (2002), halk hikâyelerinin masallarla benzer kaynaklardan beslendiğini, hatta birçok Türk halk hikâyesinin Koca Nine Masallarından alındığını belirtir (Boratav, 2002, 48). Masalların anlatıcısının kadın olması ve çoğunlukla ninelerin torunlarına masal anlatması geleneği, masalların içeriklerini de etkilemiş olmalıdır. Masal, yaşlı ka- 
dının, dişil bilgeliği kız torununa aktarmak için seçtiği bir yoldur. Nitekim Boratav (2000) masalların, "anlatma ve yayılma işinin daha çok kadınlarca benimsenmiş" olduğunu ve "bu anlatı türünün 'kocakarı masalı' diye adlandırıldığını" söyler. (Boratav, 2000, s.84).

\subsection{Tehlike: Kurt-yakışıklı genç adam}

Masalda kurt, ormanda kızla karşılaşınca hem ninesini hem kızı yeme fikriyle heyecanlanır ve kızı, yolunu uzatmaya ikna edebilmek için ormandaki çiçekleri ve kuşları göstererek ısrarla kızın yanında yürür: "Kurt bir süre Kırmızı Başlıklı Kız'la beraber yürümüş." (GK, 2015, s. 64). Yürürken de kızı, yolunu uzatarak ormanda güzel çiçekler toplamak için ikna etmeye çalışır. Kız ilk başta kararlı adımlarla büyükannesinin evine doğru yürüyüşüne devam ederse de çok geçmeden kurdun cazip önerisine uyar, büyükannesine güzel çiçekler götürmek fikri de iyi bir mazerettir: "Sonra da yolundan sapıp ormanın içine girmiş, çiçek toplamaya başlamış." (GK, 2015, s. 64).

Aytmatov'un öyküsünde, İlyas ile Asel'in tanıştıkları sahnede İlyas, hızlı ve kararlı adımlarla yoluna devam eden Asel'e kamyonuyla yetişir ve kızı kamyonuna çağırır. Teklifi kabul etmeyip bir süre yolunda yürümeye devam eden kızın peşinden giden İlyas, önce kamyonuyla, sonra kamyondan atlayıp yürüyerek kızı takip eder ve sonunda kızı kamyona binmeye ikna eder (Aytmatov, 1974, s. 188). Kırmızı Başlıklı Kız'ın çiçek toplamak için kurdun gösterdiği yoldan gitmeye kolayca ikna olmasına benzer biçimde Asel de fazla direnmeden İlyas'ın kamyonuna atlar; bu kolay zafere İlyas şaşar: "Durumuma mı acıdı, yoksa aklına başka bir şey mi geldi, bilmem artık: başını şöyle bir salladıktan sonra bindi kamyona.” (Aytmatov, 1974, s. 188). Görünen o ki, genç kız meraklı ve hazlarla dolu bir keşif yolculuğuna çıkmaya isteklidir.

Masalda kurt figürünün, küçük kızları ayartarak yollarından saptıran tehlikeli erkeklerin metaforu olduğunu düşündürebilecek birçok ögeden biri şu bölümde karş1mıza çıkar. Avcı, büyükannenin evinden gelen horultuları işitip eve girdiğinde karnı şiş vaziyette horlayarak uyuyan kurdu görür: "Gökte ararken yerde buldum seni, eski günahkâr" (GK, 2015, s. 64). İyi ve erdemli, kurtarıcı erkek karakter olan avcının, kurdu, insanlar için kullanılan bir sıfatla "günahkâr" olarak nitelenmesi dikkat çekicidir. Öyküde de Aytmatov'un, hikâyeyi İlyas'ın gözünden anlatarak onunla duygudaşlık kurma çabasına karşın aileyi temsil eden annenin gözünden İlyas'ın tehlikeli bir ayartıcı olduğunu açıklıkla görülür. Anne, Asel'i sormak için evine gelen İlyas'a hiddetlenerek "Sevgili kızımı baştan çıkardıktan sonra bir de sıkılmadan buraya geliyorsun!" diyerek İlyas'1 kovar (Aytmatov, 1974, s. 248).

Masalın bazı modern uyarlamalarında, kız kurtla evlenir; İrlandalı yazar Sommerville tarafindan yapılan bir uyarlamada, kızın evlendiği Curley isimli karakter aslında erkek kılığına girmiş bir kurttur (Zipes, 1993, 55-56). Türk halk masallarını inceleyen Pertev Naili Boratav, hayvanlarla insanların ilişkilerini odağına alan masalların ba- 
zılarının, "masal ile gerçek maceraların "masallaşmış biçimleri' diye tanımlanacak" biçimde gerçekle düşsel olanın sınırında konumlandırılabilecekleri gözlemini yapar (Boratav, 2000, s. 80). Buna örnek olarak verdiği "genç bir kızı kaçıran, onunla 'evlenen' ayıya" ilişkin hikâyenin, masalların ve efsanelerin ortaya çıkmasındaki etkenlerin araştırılması bakımından önemli bir anlatı olduğunu vurgular (Boratav, 2000, s. 80). Mitlerde ve masallarda insan-hayvan ilişkisinin çok yakın olduğu, birbirine dönüşme anlatılarının da çok yaygın olduğu bilinmektedir. Grimmlerin ve Perrault'nun Kırmızı Başlıklı Kız masalında kız kurtla evlenmez ama kurdun kandırmasıyla onunla aynı yatağa girer ve bu sahne, sembolik anlamlarıyla birçok yoruma konu olmuştur.

Hint-Avrupa masallarında "kurt adam" (werewolf) figürünün yaygın olduğunu ve bu figürün kökeninin şamanlara kadar geriye götürüldüğünü, Avrupa'da Ortaçağ'da cadıların yanı sıra kurt adamların da gerçekte var olduğuna inanıldığını hatırlamak gerekir (Duggan, 2016, s. 497, s. 499). İlyas ile Kurt arasında bir koşutluk görülebilir; masum bir kızı, aile ve geleneklerin çizdiği yoldan çıkarıp sonra terk eden İlyas'ın hikâyede, epey kötücül bir işlevi yerine getirdiği açıktır. Kırmızı Başlıkı Kız masalının cinsel çağrışımları olduğunu öne süren okumaların da bulunduğu düşünüldüğünde İlyas, Asya'yı veya Kırmızı Başlıklı Kız'1 "yutmaya” hazırlanan Kurt olarak görülebilir. Bu tür benzerlik veya alışverişlerin ortaya çıkartılması için mitlerin, masalların ve halk hikâyelerinin kültürlerarası karşılaştırmalarla ele alınması ve Batı dünyasında yapılan akademik çalışmalarda az temsil edilen "Orta Doğu, Balkanlar, Uzakdoğu" gibi bölgelerde üretilen metinlerin, bu çalışmalardaki ağırlığının artırılması gerekliliği, önemli bir saptamadır (Birkalan-Gedik, 2006).

\subsection{Kurtarıcı: Avcl-yol mühendisi}

Masalın kurtarıcısı bir avcıdır: "Kurt amacına ulaşınca, yeniden yatağa uzanmış ve yeri göğü birbirine katarak horlamaya başlamış. Avcı da tam o sırada evin önünden geçiyormuş: 'Bu yaşlı kadın nasıl da horluyor, gidip bakayım bir sıkıntısı mı var?" (GK, 2015, s. 65). O kadar iyi bir karakterdir ki ufak bir şüpheyle harekete geçerek yaşlı kadına yardımcı olmak için eve girer ve sonrasında da iyi düşünülmüş adımlarla kurbanları kolayca kurtarır. Selvi Boylum Al Yazmalım öyküsünün kurtarıcı kahramanı Baytemir'in öyküye dâhil olması da ne tesadüftür ki yaşlı bir kadına yardım etmesiyle olur; bir komşusunun hasta annesini hastaneye götürmüştür ve kadınla birlikte bir kamyonun kasasında geri dönerken Asel de aynı kamyona biner (Aytmatov, 1974, s. 281). Hiç karşıllık beklemeden herkese yardım eden bir karakter olan Baytemir, çalışkan ve becerikli bir adamdır; yol ustasıdır ve Asel ile evlendikten birkaç sene sonra kamyonuyla kaza yapmış olan İlyas'a da yardım elini uzatacak, onu eve getirecektir. Filmde Cemşit adını alacan bu kurtarıcı kahraman, aynı özellikler ve olay örgüsü içinde Aytmatov'un öyküsündeki işlevleri başarıyla yerine getiren her zaman sorun çözen, olumlu bir figürdür ve film üzerine Türk sinema izleyicisi arasında yapılan "İlyas mı, Cemşit mi?" (veya "Kadir İnanır mı, Ahmet Mekin mi?") eksenindeki anket benzeri sorgularda İlyas karşısında epey güçlü bir seçenektir. 


\subsection{Baharda canlanan doğa ve aşkla özgürleşme}

Buraya kadar Kırmızı Başııkı Kız, Asel ve Asya karakterlerini, baştan çıkarılan masum kız; kurt ve İlyas'ı da kötücül baştan çıkarıcı figürler olarak okuduk. Artık bu "baştan çıkma" durumunun bütünüyle de gönülsüz olmadığını, kızın da kendisini keşfetmeyi ve özgürleşmeyi istediğini düşünme zamanı geldi. Gilles Deleuze ve Felix Guattari, bir özgürleşme olarak "oluş" kavramını ortaya atarlar ve ataerkil toplumun kısıtlamalarının hâkim olduğu "çoğunluksal" alandan kaçarak "azınlıksal" olan alanda özgürleşmek için her türlü mahrem ilişkinin ve özellikle de "aşk" $1 n$ işlevsel olduğunu söylerler (aktaran Pekerman 2012, s. 37). Öyküde Asel ve filmde Asya da İlyas'a duyduğu aşk ile özgürleşme hissi yaşar. Makalede ele aldığımız üç eserde de deneyimsiz küçük kızın geleneklerin getirdiği sınırları yoklayarak, yol metaforu üzerinden özgürleşme ve kendini bulma çabası anlatılmaktadır.

Aşk ile özgürleşme izleğine ilkbaharda canlanan doğanın eşlik etmesi de yine üç metinde de yer alır. Masalda kurt, kızın yolunu uzatarak büyükannenin evine önceden ulaşabilmek için ormanın güzelliklerini anlatır ve kız da bu doğa tablosunun çekiciliğine kapılır:

"Kırmızı Başlıklı Kız, etrafındaki şu güzel çiçekleri görüyor musun? Niye hiç dönüp bakmıyorsun? Galiba kuşların ne güzel öttüğünü duymuyorsun. Sanki okula gider gibi hiç sağına soluna bakmadan yürüyorsun, oysa ormanda hayat çok eğlencelidir" demiş.

Kırmızı Başlıklı Kız gözlerini yukarı çevirmiş, güneş ışınlarının ağaçların arasında bir belirip bir kaybolarak dans ettiklerini, her tarafinda da güzel çiçeklerle dolu olduğunu görünce, "Büyükanneme bir demet taze çiçek götürürsem çok sevinir; vakit henüz çok erken, nasıl olsa tam saatinde ulaşırım” diye düşünmüş. Sonra da yolundan sapıp ormanın içine girmiş, çiçek toplamaya başlamış. Bir çiçeği koparınca, "İleride daha güzelleri var" diye düşünmüş, böylece ormanın derinliklerine iyice dalmış. (GK, 2015, s. 64).

Mevsim ilkbahardır ve Kırmızı Başlıkıı Kız, büyükannesinin evine giden en kısa yolu terk ederek baharda canlanan doğanın güzellikleri içinde neşeyle ilerler.

Öyküde Asel'in "yoldan çıkması" da baharda ve benzeri bir pastoral atmosferde gerçekleşir. Asel, kütüphaneden dönerken İlyas'ın geçeceği yeri tahmin edip yol kenarında onu bekler ve geldiğinde de kamyonuna biner. İlyas'ın, "Atla içeri, Asel, gezelim biraz" sözüyle başlayan gezi, "bozkır yolunda kuş gibi uçan” kamyonda, İlyas'ın bakışından anlatılan coşkulu bir doğa ve aşk kutsamasına dönüşür (Aytmatov, 1974, s. 203). Rüzgâra karşı giderlerken "dağlar, tarlalar, ağaçlar" ikisine doğru geliyor gibidir. Aslında hareket eden onlardır ve onlar doğanın güzelliklerine yöneldikçe doğa da onlara yanıt verir: "Pırıl pırıl güneşe karşı sevinçle gülmeye başladım. Pelin otu ve lâle kokan havayı ciğerlerimize doldurduk." (Aytmatov, 1974, s. 203). İkisi kamyonda bu şekilde ilerlerken, karşıdan gelen at arabasında bir genç çift ayağa kalkar, İlyas ile Asel'e "omuz omuza" el sallarlar (Aytmatov, 1974, s. 204). İlyas ile Asel, sanki bir geçit töreninde ilerlemektedirler ve herkes onların aşklarını kutla- 
maktadır. Devamında da güzel, pastoral bir atmosfer çizilir; dağlar, göl, "köpüklü mavi dalgalar", "tepeleri karlı mor dağlar", batmakta olan güneşle pembeleşen sular, kuğular tam bir romantik idealizasyon içinde doğa ve aşk olumlaması yapılır (Aytmatov, 1974, s. 204). Sonuçta, kısa bir gezinti olmaktan çıkan bu macera, patlayan firtına, kamyonun camlarına vuran yağmur damlaları altında İlyas'ın, "Kimsenin seni üzmesine göz yummayacağım; al yazmalım, selvi boylum benim" diye kızın kulağına aşk sözleri fisıldadığı bir kavuşma sahnesine dönüşür (Aytmatov, 1974, s. 204). Geceyi kamyonda geçirdikten sonra ertesi sabah İlyas'ın çalıştı̆̆ ulaştırma merkezine giderler; Asel evi terk etmiştir, evleneceklerdir (Aytmatov, 1974, s. 206).

Filmde aynı pastoral romantizm atmosferini barındıran ve iki genç arasındaki aşkın ilkbaharın güzellikleri arasında coşkuyla kutlandığı etkileyici sahnede, İlyas ile Asya'nın kamyonda neşe içinde ve çevrelerine selam vererek, öyküdeki gibi geçit törenine benzer bir biçimde ilerlediklerini görürüz. Filmi iç seslerle karakterlerin iç konuşmalarına da yer verir. İlyas, Asya'nın evine gelir, kapıda ikisinin de iç seslerini duyarız. İlyas "Elinden tutuversem benimle gelir mi?" diye düşünür, Asya, "Seninim işte. Alıp götürsene" diye düşünür ve koşarak kamyona biner. Yolda, İlyas'ın kahkahasıyla başlayarak Asya'ya da bulaşan bir neşeyle hızla ilerlerler; İlyas'ın Gönül adını vererek kişileştirdiği kamyon da neşelerine katılarak zikzaklar çizer. İlyas yolda gördüğü herkese seslenerek "Hoş geldin deyin sevgilime" diye haykırır. Öyküdeki gibi bir at arabası geçer ama ayağa kalkıp el sallayan bir genç çift yoktur. İlyas, tarlasında traktör süren bir adama, otlayan keçilere seslenir. Asya da "Hoş gördük yüce kale, hoş gördük yalnız çınar, sevgilin nerede? Hoş bulduk sakallı keçi” diye neşeyle bağırarak yanıt verir. İkisi de kamyonun pencerelerinden dışarı uzanarak, el sallayarak ilerlerler; gökyüzüne, güneşe, tarlalara, coşkun dereye seslenerek ilerleyişleri, Aytmatov'un metninde Asel ile İlyas'ın yine kamyonda yaşanan kaçış sahnelerindeki doğayla sarmalanmış geçit töreninin Anadolu coğrafyasında ve sinema teknikleri ile zenginleştirilmiş başarılı bir uyarlamasıdır. Sanki bütün doğa onlar için bir tören düzenlemiştir. Emel Kefeli (2009), Aytmatov'un yapıtlarında "metnin anlatımını görsel bakımdan destekleyen ve kurguda özel bir işlev yüklenen" betimlemelerin dikkat çektiğini belirterek (s. 189), yazarın, doğaya dair ögelerin de özel bir yer tuttuğu bu betimlemeler yoluyla "okurun zihninde sosyo-kültürel atmosferi yaratmak ve karakterlerin hayatlarındaki trajik boyutu vermek" hedeflerine ulaştığının altını çizer (s. 190). Gerçekten de evden, geleneklerin baskısından kaçan Asel'in ve Asya'nın İlyas ile kavuşması, hem romantik hem de trajik açılımları olan bir eylemdir. Geceyi göl kenarında kamyonda geçirirler ve ertesi sabah da birlikte yeni bir hayata başlarlar.

\section{Sosyokültürel bağlam: Ataerkil kalıplar ve özgürleşme mücadelesi}

Selvi Boylum Al Yazmalım'ın setinde, filmin finali konusunda bir kriz yaşanmıştır. Ali Özgentürk (2018) anılarında, filmin çekimi devam ederken, yazdığı senaryodaki final sahnesinin değiştirilmek istendiğini, Türkan Şoray'ın, filmin sonunda Asya ile İlyas'ın kavuşması fikrinde 1srar ettiğini belirterek buna şiddetle karşı çıktığını, 
Asya'nın “tutkuyla âş̧k olduğu İlyas'ı (Kadir İnanır) değil, ona ve çocuğuna emek veren Cemşit'i (Ahmet Mekin)" seçmesi gerektiği konusunda kararlılık gösterdiğini kaydeder (s. 52). Sonunda, Özgentürk'ün istediği olur, Asya İlyas'1 geri çevirir ve Cemşit'e gider. Böylelikle, star odaklı Yeşilçam sinemasından yönetmen ve senaryo ağıllıklı yeni sinemaya geçiş sürecinin kritik adımlarından biri de atılmış olur. Aytmatov'un metninde de Asel, İlyas'ın yeniden bir araya gelme teklifi karşısında "bir trajik çatışma" (Korkmaz, 2004, s. 178) yaşar ama kendisine emek veren ve hâline acıyıp kurtaran adamı, Baytemir'i tercih eder (s. 178). Ramazan Korkmaz (2004), bu seçimle Aytmatov'un, "sevginin emek ve empati ile oluşturulan yüksek bir değer olduğu gerçeğini”" göstermek istediğini belirtir (s. 178).

Öte yandan kadının, ayrılık ânında da çok sevdiği belli olan İlyas'ı reddedip kendi arzularını, çocuk ve aile için feda ettiği bu final, ataerkil toplumsal cinsiyet kodlarını barındırır görünmektedir. Erkek egemen toplumsal cinsiyet rollerinin edebiyat metinlerinde ve masallardaki temsillerini ortaya çıkartmak, feminist edebiyat kuramının önemli bir başarısı olmuştur. Masal çalışmaları alanında 1970'lerden itibaren gelişen bir feminist birikim vardır.

\subsection{Küçük kızlara ahlak dersi}

Karen Rowe (1979), alanında çığır açan makalesi "Feminism and Fairy Tales" (Feminizm ve Olağanüstü Masallar) ile masalların sosyokültürel işlevlerini sorgulayarak, "romantik beklentilerimizi biçimlendiren paradigmaların ortaya çıkartılmasında halk masallarının feminist perspektiften incelenmesinin" önemine işaret etmiştir (s. 237). Rowe (1979), "kadınların, edilgenlik, yardıma muhtaç hissetme ve kendilerini feda etme gibi kültürel normları kadına özgü yüce değerler olarak olağanüstü masallardan gerçek hayata taşıyabileceğini ve böylelikle olağanüstü masalların, ataerkil statükonun ve kadınların değersizleştirilmesinin, romantik olarak arzulanan ve hatta kaçınılmaz bir kader olduğu düşüncesini yaygınlaştırdığını" vurgular (s. 237). Üstelik çocuklukta okunan veya dinlenen masalların yanı sıra yetişkin edebiyatına ve sinemaya uyarlanan masallarda da aynı yapının devam etmesi, etkiyi daha da kuvvetlendirir. Kırmızı Başlıklı Kız masalının da benzeri bir bağlamda işlevselleştirildiği görülmektedir.

Masalın, Perrault tarafindan kayıt altına alınmadan önce Fransız sözlü geleneğinde yer alan hâlinde, kızın ya kendi çabasıyla ya da bir kurtarıcı yardımıyla kurtulduğu bilinmektedir (Dundes, 1989, s. 3). Oysa Perrault masal, kız ve büyükannenin ölümüyle bitirdiği gibi bu trajik sonun hemen arkasında bir ibret mesajına yer vererek metni, ders verme amacı güden bir anlatıya dönüştürmüş olur (Dundes, 1989, s. 3). Anlatıc1nın sesinden verilen bu kıssadan hisse bölümü, şiir biçimindedir. Mesaj, masalın okur veya dinleyici kitlesine doğrudan hitap eder: "Bu hikâyeden öğreniyoruz ki çocuklar, özellikle güzel, kibar ve iyi yetişmiş genç kızlar, yabancılara inanmakla çok yanlış yapıyorlar." (Perrault, 1989, s. 6). "Yabancılar" sözcügü ile fabllara özgü hayvandan insana alegorik bir geçiş yapılarak tehlikeli kurtların insan formunda da olabileceği iması yapılmış olur. Bölüm, en büyük tehlikelerin "yumuşak huylu, yardımsever ve kibar" 
kurtlardan geleceğinin vurgulanmasıyla biter (Perrault, 1989, s. 6). Grimm Kardeşler versiyonunda ise ahlak mesajını veren anlatıcı değil, kızın kendisidir; Türkçe çeviride bulunmayan bu bölüm, masalın Jack Zipes tarafından yapılan İngilizce çevirisinde şu şekilde yer almaktadır: "Kırmızı Başlıklı Kız kendi kendine düşündü: 'Bir daha asla annen yasaklamışken kendi başına yoldan sapmayacaksın ve ormana gitmeyeceksin' " (GK 2014, s. 87). Kızın iç konuşması olarak sunulan bu ifade ile ibret mesajının içeriğinin değişmediğini ama küçük kızın yaşadıklarından ders çıkararak bir daha aynı hatayı yapmamak üzere kendisine telkinde bulunduğunu görüyoruz. Kırmızı Başlık1ı Kız'ın iç konuşması, akla Selvi Boylum Al Yazmalım filminin finalinde Asya'nın, "Sevgi Neydi? Sevgi emekti” ile biten iç konuşmasını getirir. Genç kız doğru kararı, yaşadıklarından ders çıkararak kendi aklıyla almış gibidir ama ona, yanlış seçimlerinin getireceği tehlikeleri yaşatarak "eğitim" veren bir örtük yapı olduğu da açıktır.

Özellikle kadın bedeni üzerinde icra edilen denetim ve yasaklamaların kökleri eski çağlara dek uzanmakla birlikte Batı'nın cinselliğe bakışının 18. yüzyılda geçirdiği ve "ilk cinsel devrim" olarak adlandırılan değişimler bu denetim isteğini artırmış görünmektedir (Stearns, 2016, s. 167). 18. yüzyıldan itibaren tarımdan ticarete geçiş, Aydınlanma Çağ 1 ile gelen özgürleşme ve seküler bakış açısı, kapitalizmin sonucu olarak iyi beslenme ve kentleşme ile ergenliğe giriş yaşının düşmesi ile bir cinsel kargaşa dönemine girilmiştir (Stearns, 2016, s. 165). Ergenliğe geçiş yaşının düşmesi, cinsel ilişki olasılıklarının ve evlilik dışı doğumların artmasına yol açmış, Avrupa'da sahipsiz çocuklar meselesi ortaya çıkmıştır (Stearns, 2016, s. 169-170). 19. yüzyılda iyice görünür hâle gelen bu cinsel kargaşanın sakıncalarına karşı mücadelede çocuklara özel bir önem verilmiş, Ortaçağ'ın egemen kurumu olan Kilise'nin artık gücünü yitirmiş olması nedeniyle cinselliği denetim altına almak için modern uygarlığa uygun yollar aranmıştır (Stearns, 2016, s. 169). Michel Foucault (2018), 18. yüzyıldan başlayarak, "cinselliğe ilişkin özel bilgi ve iktidar tertibatları geliştiren" yöntemler arasında "çocuk cinselliğinin eğitimbilimselleştirilmesi” (pedagojikleşmesi) olgusunu sayar (s.76). Böylelikle, "cinselliğin hem ötesinde hem de bilfiil içinde olmaları nedeniyle tehlikeli bir paylaşım çizgisi üzerinde yer alan" çocukların cinselliği, "ana babalar, aileler, eğitmenler, doktorlar, psikologlar" tarafından denetim altına alınabilecektir (Foucault, 2018, s.77). Olası bir çocuk cinselliğinin tehlikelerine karşı en etkili uyarı ve denetim, çocuklara anlatılan masallar ve hikâyelerle sağlanmaya çalışılmış ve masallara toplumsal ve ahlaki bir görev yüklenmiştir. Kırmızı Başlıklı Kız masalı, bu bağlamda devreye girerek, kız çocuklara, kendilerini yabancılardan korumaları ve ailenin koydugu kurallara uymaları konusunda uyarı amaçlı olarak anlatılmaya başlanmıştır. Charles Perrault tarafından yayımlanan ilk yazılı versiyonda, kurallara uymayan kızın ve büyükannesinin kurt tarafindan vahşice öldürülmesi ve bu versiyonun 17. yüzyıl sonunda ortaya çıkarak 18. yüzyıl boyunca yaygın olarak okunması, hem bir rastlantı olmayıp yukarıda açıkladığım toplumsal meselelerle yakından ilişkilidir, hem de çocuk masallarında rastlanmayan vahşi sonu nedeniyle Perrault'nun okur kitlesinin çocuklardan ziyade genç kızlar olduğunu düşündürmektedir. 
Zohar Shavit (1989) 17. yüzyıla kadar Avrupa'da çocukların birer küçük yetişkin olarak görüldüklerinden yola çıkarak masal ve hikâyelerin, aralarında çocukların da bulunduğu karışık bir okur ve dinleyici kitlesi olduğunu ve zamanla çocuklar için ayrı bir edebiyat oluşmuş olsa da aradaki bu geçişkenliğin Perrault'nun Kırmızı Başlıklı Kız versiyonunda hem çocuk ve hem de yetişkin okurlara yönelik ögelerin yer almasina neden olduğunu belirtir (s. 142). Özellikle Perrault'nun sözlü gelenekten gelen masalın mutlu sonunu değiştirerek, masallarda rastlanmayan trajik bir kötü son yazmış olmasının, masalın çocuklara değil yetişkinlere hitap eden bir yönü olduğunun kanıtıdır (Shavit, 1989, 142). Masalın Grimm Kardeşler versiyonunda trajik bir son olmay1\$̧1, metni çocuk edebiyatına yaklaştıran bir ögedir ama benzeri bir ahlak dersi, Alman versiyonunda da küçük kız tarafından içselleştirilir.

\subsection{Kadının bireyleșme çabası}

Aytmatov'un öyküsünde Asel'in duyguları, iç dünyası hakkında bir bilgi yoktur; tüm anlatı, erkek karakterlerin bakış açısından sunulur. Filmde ise Asya, baskıcı annesinden kurtulmak isterken, yolda tanıdığ 1 çekici yabancıya adım adım kapılırken, terk edildiğinde evde oturup beklemeyi reddederek çocuğunu kucağına alıp bilinmezliğe yürürken ve ona güvenli bir yuva sunan Cemşit'e rağmen kalbinden atamadığ İlyas'a son bir kez aşkla bakarken, duyguları ve iç çatışmalarıyla gerçek bir insandır.

Evrim Ölçer Özünel (2017), masalları, toplumsal cinsiyet ve mekân ilişkisi bağlamında incelediği çalışmasında, erkek egemen toplum yapısı içinde kadının güzelliğinin, mitolojide "kışkırtıcı fitne" (s. 64) ile bağdaştırıldığını ve erkek tarafından arzulanan kadının ancak ev içinde var olmasına izin verildiğini belirterek kadın bedeni ile ev arasında bir koşutluk kurar: "Kadın bedeni de tıpkı ev içi mekânın sağlam duvarlarına benzer bir örülüşe sahiptir. Kadın bedeninin bir arzu nesnesine dönüştürülmesi, beden algısının kadim zamanlardan beri, kadının bilinci etrafına örülmüş bir duvar olduğunu düşündürmektedir. Dolayısıyla, kadın bedeninin erkek tarafından arzulanan nesne olmasıyla, kadının yalnızca ev içinde var olabilmesi arasında bir bağlantı vardır." (Ölçer Özünel, 2017, s. 63-64). Masalda olduğu gibi öyküde ve filmde de genç kadın sonunda kendisinden beklenen seçimi yapar ve bu "doğru seçim" evde olmaktır.

Kırmızı Başlıklı Kız'ın Grimm Kardeşler versiyonunda, kız çocuğunun ahlak dersini, kendi aklıyla aldığından söz etmiştik. Asel ve Asya da benzeri bir dersi, belli ölçüde kendi çabalarıyla alır ve benimserler; her ikisi de sonuçta annelerinin bulduğu kişiyle değil, ev dışında arayış içindeyken karşılaş̧ıkları adamla evlenirler. Böylelikle, Grimm Kardeşlerin Kırmızı Başııklı Kız'a tanıdığı oranda bir özgürlük, Asel ve Asya'ya da sunulur. Bu izlek, bir anlamda kadının, verili sınırlar içinde gerçekleşen bireyleşme sürecidir. Genç kız, içine hapsedildiği baskıcı düzenden, namusunun bekçisi annesinden ve tanımadığı biriyle zorla evlendirilmekten kaçar ve özgürleşmek için yollara düşer, sonunda âşık olduğu adama kavuşamasa da ailesinin dayattığı kişiyi bertaraf eder ve yine kendi bulduğu birisiyle evlenir. Sınırları büsbütün ortadan kaldıra- 
masa da onları zorlar, esnetir. Kalıplara, kurallara direnir ve sonunda bir uzlaşı formülü yaratır. Bu uzlaşı, ataerkil baskılar kadar, bu baskılara direnen ve onları aşındırmaya çalışan dişil bir enerjinin de etkili olduğunu kanıtlar.

Son olarak, Kırmızı Başlıklı Kız masalını bir büyüme hikâyesi olarak okuyan Bruno Bettelheim'dan söz edeceğiz. Masallara psikanalitik kuramın perspektifinden yaklaşan Bettelheim (2019), çocuğun bilinç dışındaki çatışmaları bilinçli benliğinde anlayıp onlarla baş edebilmesinin, akılcı yöntemlerle mümkün olmadığını, bunu ancak hayaller kurarak yapabileceğini söyler (s.12). Çocuk, kendi doğasının karanlık yönleri de dâhil olmak üzere "bilinç dışı baskılara karşılık olarak uygun hikâye unsurları hayal etmek, bunları yeniden düzenlemek ve bunlar üzerine düşünmek" yoluyla kendi bilinç katmanlarının farkına varır (Bettelheim, 2019, s.12). Varoluşsal sorunlarla "nasıl başa çıkabileceği ve ergenliğe nasıl güvenle adım atabileceğine dair bilhassa sembolik biçimde önerilere" ihtiyaç duyan çocuğun imdadına masallar yetişir (Bettelheim, 2019, s.13). Kırmızı Başlıklı Kız da bu açıdan bakıldığında yepyeni anlamlar kazanır. Masalın Alman versiyonu, haz arayan alt bilinci ile sorumlulukları arasında bir denge kurmaya çalışan kız çocuğunu, "sembolik biçimde ergenlik boyunca yaşadığı ödipal çatışmaların tehlikelerine maruz bırakır, sonra da çatışmasız bir şekilde olgunlaşabilsin diye onlardan kurtarır" (Bettelheim, 2019, s. 221). Karakterler bu bakış açısına göre işlevler üstlenmiş̧ir: Kız, "erkeğin kişiliğinin tüm yanlarını görerek onun çelişkili tabiatını anlamaya çalışan" bir karakterdir; kurt, bilinç dışını ve dolayısıyla "bencil, asosyal, şiddetli ve yıkıcı potansiyeldeki eğilimleri", avcı ise "özverili, sosyal, düşünceli ve koruyucu eğilimleri” temsil eder (Bettelheim, 2019, s. 221). Özetle bu yoruma göre küçük kızın, olayların sonunda bir daha yoldan çıııp ormana girmeyeceğine ilişkin olarak kendisine söz vermesi, deneyimlerinden ders çıkardığının, dönüşümünü ve büyüme sürecini sağlıklı olarak tamamladığının işaretidir (Bettelheim, 2019, s. 234). Öyküde ve filmde de aynı olgunlaşma süreci söz konusudur. Filme ilişkin popüler kültürde yapılan yorumlarda kadın izleyicilerin, filmi genç yaşlarda izlediklerinde İlyas'ı, evlenip yaş aldıktan sonra ise Cemşit'i seçmeleri, eserdeki büyüme temasının izleyicide bir karş1lığı olduğunu düşündürmektedir.

\subsection{Yazar, metin ve bağlam: Cengiz Aytmatov'un evrenselliği}

Cengiz Aytmatov küçük yaşlarından itibaren çok yakın olduğu babaannesini tam bir sözlü kültür hikâye anlatıcısı olarak tarif eder ve ondan dinlediklerinin, yazarlığına çok katkısı olduğunu vurgular (Kolcu, 2002, s.30). Gerek ninesinden gerek Kırgız halk ozanlarından dinlediği hikâyeler sayesinde masallar, efsaneler ve mitlerle örülü zengin bir sözlü kültür birikimine sahip olduğu anlaşılan Aytmatov, romanlarında bu malzemeden beslendiğini şu sözleriyle belirtir: "Hülâsa mitolojik zenginlikleri romanlarımda değiştirerek, bugünkü hayatın gerçekleriyle, istek ve temennileriyle bağdaştırarak bol miktarda kullaniyorum" (aktaran Kolcu, 2002, s. 48, 49). Aytmatov'un hikâye birikimi yerel malzeme ile de sınırlı değildir; erken yaşlarda Rus edebiyatının klasikleriyle tanışmış (Ükübeva, 2019, s. 47); Moskova'da, Gorki Edebiyat Enstitüsü’nde ve 
Moskova Üniversitesi Edebiyat Fakültesi'nde eğitim gördüğü sırada, "Rus ve dünya edebiyatının önemli eserlerini okumuştur." (Akmataliyev, 1998, s. 16, Kolcu, 2002, s. 33, Ükübeva 2019, s. 48).

Dünya çapında geniş bir okur kitlesine ulaşmış olması, yazarın bazı evrensel izlekler ve imgeler ile yakın ilişki içinde olduğunu düşündürmektedir. Nitekim bir söyleşide Aytmatov, her yazarın öncelikle kendi milletinin kültüründen beslenmesi gerektiğini vurguladıktan hemen sonra şunları söylemiştir: "Yazar, ufkunu millî olanın ötesine doğru genişletmek "evrensel” olana ulaşmak için gayret göstermek zorundadır" (aktaran Kolcu, 2002, s. 45-56). Doğu’yu da Batı'yı da, sözlü kültürü de edebiyatı da iyi bilen bir entelektüel olan Aytmatov'un Selvi Boylum Al Yazmalım adlı öyküsünün bugüne kadar sadece yerel bağlamda ele alınmış, olası kültürlerarası ve metinlerarası ilişkileri yeterince araştırılmamıştır. Bu makalenin bulgularının da işaret ettiği üzere Aytmatov'un eserlerinin, karşılaştırmalı bir yöntemle ele alınacağı yeni çalışmalar yapılmasının, eserlerin çok katmanlı niteliklerine 1şık tutacaktır.

\section{Sonuç}

Bu çalışmada, Aytmatov'un Kırgız toplumsal ve kültürel bağlamı içinden üretilmiş Selvi Boylum Al Yazmalım adlı uzun öyküsünün, Batı Avrupa masal geleneği içinde 18. ve 19. yüzyıllarda kız çocuklarına ahlak dersi vermek amacıyla yaygın olarak okunan ve anlatılan Kırmızı Başlıklı Kız masalı ile yakın metinlerarası ilişkiler içinde olduğunu; benzer şekilde, bu öykünün sinemaya uyarlaması olan filmin de sözü edilen masala ait ögeler barındırdığını ve bunları sinema diliyle çok daha can1 biçimde ifade ettiğini sergiledik. Aynı olay örgüsü ekseninde kurulmuş olan üç metni birbirine bağlayan işaretler ve anlatı ögelerini ve bu ögelerin, ataerkil toplum yapısı ile ortaklaşan ve aynı zamanda bu yapıyı belli ölçüde aşındırarak kadına göreli bir özgürlük sağlayan yönlerini vurguladık.

Selvi Boylum Al Yazmalım filminin, kadının bakış açısı ve duygularına yer veren anlatım teknikleriyle Aytmatov'un metninden ayrıldığını ama sonunda genç kızlara benzer bir uzlaşı reçetesi önerdiğini; kadının, ancak ataerkil yapı içindeki toplumsal cinsiyet rolüne sadık kalarak var olabildiğini gördük. Böylelikle, Yeşilçam'ın en güzel aşk filmlerinden biri olarak hatırlanan yapımın, aslında bir aile güzellemesi olduğunu ve kadınlara, erkek egemen yapıya uygun bir büyüme ve toplumsallaşma süreci önerdiğini gördük. Burada yine de tek taraflı bir ataerkil baskıdan değil, bu baskıya direnerek bireyleşmeye çalışan bir kadın kimliğinden de söz edebileceğimiz sonucuna vardık. Aytmatov'un öyküsünde de görülen, kadının, belli sınırlar içinde kalmak koşuluyla ataerkil kısıtlardan ve değersizleştirmeden kurtulduğu yapı, Asya'nın duygularını izleyiciye ulaştıran filmde daha açık biçimde ortaya çıkmaktadır. Bireysel arzular ile toplumun beklentileri arasındaki gerilimin ikinciden yana sonuçlanması, ancak bu süreçte kadının da belli ölçüde bireyleşebilmesi, filmin kalıcı etkisini açıklayabilir. Ali Özgentürk'ün senaryosu ve Atıf Yılmaz'ın sinema dili kadının perspektifine ağırlık verecek biçimde kurgulandığından Selvi 
Boylum Al Yazmalım, etkili bir kadın hikâyesine dönüşmüştür; erkek egemen toplumla müzakereye girerek kopartabileceği kadar özgürlüğü elde eden bir kadının hikâyesi. Baktığınız açıya göre değişen, çeşitli arketiplerin akışkan bir birlikte varoluş içinde etki ettiği karmaşık bir kadın ve Asya ile Asel'in masallardaki izdüşümü olan Kırmızı Başlıklı Kız’ın hikâyesi.

Kırmızı Başlıklı Kız, ne kadar köklü arketipler ve evrensel çatışmalar üzerine kurulmuş olmalı ki, kültürel farklılıkların ve zamanın aşındırıcı

etkisinin ötesine geçerek çağlar, metinler ve türler arası yolculuğunu sürdürüyor.

\footnotetext{
Notlar

1 Metin içinde Grimm Kardeşler yerine GK kısaltması kullanılacaktır.

2 İngilizce cake karşılığı olarak "çörek", bu masal bağlamında "pasta” sözcüğünden daha doğru görünmüştür.

3 Yayınlarında P. Saintyes takma adını kullanan Fransız araştırmacı Émile Nourry (1870-1935).
}

\section{Kaynaklar}

Akmataliyev, A. (1998). Cengiz Aytmatov’un dünyası. Atatürk Yüksek Kurumu, Atatürk Kültür Merkezi. Aytmatov, C. (1974). Selvi boylum al yazmalım. Bütün eserleri II (ss. 178-290). (M. E. Gözlü. Çev.) Cem.

Aytmatov, C. (2018). Selvi boylum al yazmalım. (M. Özgül. Çev.) Nora.

Bettelheim,B.(2019).Masalların Büyüsü: Masalların İşlenişi, Önemi ve Psikanalitik Anlamları.(S.G. Elibal. Çev.) İnkılâp.

Boratav, P.N. (2000). 100 soruda Türk halk edebiyatı. Gerçek.

Boratav, P.N. (2002). Halk hikâyeleri ve halk hikâyeciliği. Tarih Vakfi.

Duggan, A. E., Haase, D. \& Callow, H. (2016). Folk tales and fairy tales: Traditions and texts from around the world. Greenwood.

Dundes, A. (Ed.) (1989). Little red riding hood: A casebook. Wisconsin Üniversitesi.

Foucault, M. (2018). Cinselliğin tarihi. (H. U. Tanrı̈ver. Çev.) Ayrıntı.

Grimm, J. ve Grimm, W. (2014). Little red cap. İçinde: J. Zipes (Ed.) The original folk and fairy tales of the Brothers Grimm: the complete first edition (J. Zipes, Çev), (ss. 85-88). Princeton Üniversitesi.

Grimm, J. ve Grimm, W. (2015). Kırmızı başlıklı kız. Grimm Kardeşlerden seçme masallar (s. 63-66) (M. Tüzel., Çev.), İş Bankası Kültür.

Haase, D. (2004 a). Faminist fairy-tale scholarship. İçinde: D. Haase (Ed.), Fairy tales and feminism: New approaches (ss. 1-36). Wayne Devlet Üniversitesi.

Kefeli, E. (2009). Cengiz Aytmatov ve Yaşar Kemal'de dramatik öge olarak tasvirler.

İçinde: R. Korkmaz (Ed.), Cengiz Aytmatov (ss. 189-197). Kültür ve Turizm Bakanlığı.

Kolcu, A.İ. (2002). Bozkırdaki bilge: Cengiz Aytmatov. Akçağ.

Korkmaz, R. (2004). Aytmatov anlatılarında eriştirici/dönüştürücü üç temel değer: Emek ve empati/ türküler/aşk. İçinde: Cengiz Aytmatov doğumunun 75. yılı için armağan (ss.167-195). KırgızistanTürkiye Manas Üniversitesi.

Ölçer-Özünel, E. (2017). Masal mekânında kadın olmak: Masallarda toplumsal cinsiyet ve mekân İlişkisi. Geleneksel.

Özgentürk, A. (2018). Gizli defterlerim. Kırmızı Kedi.

Pekerman, S. (2012). Film dilinde mahrem: Ulusötesi sinemada kadın ve mekân temsili. Metis. 
Perrault, C. (1989). Little red riding hood. İçinde: A. Dundes (Ed.), Little Red Riding Hood: A casebook (ss. 4-6). Wisconsin Üniversitesi.

Propp, V. (2017). Masalın biçimbilimi. (M. Rifat, S. Rifat Çev.) İş Bankası Kültür.

Rowe, K. E. (1979) Feminism and fairy tales. Women's Studies: An inter-disciplinary journal, 6:3, 237257, DOI: $10.1080 / 00497878.1979 .9978487$

Shavit, Z. (1989). The concept of childhood and children's folktales: Test Case-Little Red Riding Hood. İçinde: A. Dundes (Ed.), Little Red Riding Hood: A casebook, (ss. 132-158). Wisconsin Üniversitesi.

Stearns, P. (2016). Cinselliğin kısa tarihi. (H. Dikmen. Çev.) Dedalus.

Ükübeva, L. (2019, Ocak). Cengiz Aytmatov. Türk Edebiyat1, 543, 45-51.

Yılmaz, A. ve Özgentürk, A. (1977). Selvi Boylum al yazmalım. Çiçek Film ve Gala Film.

Zipes, J. (1993). Prologue: Framing Little Red Riding Hood. İçinde: J. Zipes (Ed.), The trials and tribulations of Little Red Riding Hood, (s. 1-88). Routledge.

\section{Elektronik kaynaklar}

URL-1: Birkalan-Gedik, H. (2006, 10 Ekim). [Donald Haase, Fairy tales and feminism: New approaches için kitap tanıtımı]. Journal of Folklore Research. (Erişim tarihi: 5 Nisan 2021) (https://jfr.sitehost. iu.edu/review.php?id=252)

URL-1: Kahraman, A. (2016). Cengiz Aytmatov. TDV İslam Ansiklopedisi. Cilt.1, 147-149. (Erişim tarihi: 21 Aralık 2020) (https://islamansiklopedisi.org.tr/aytmatov-cengiz) 